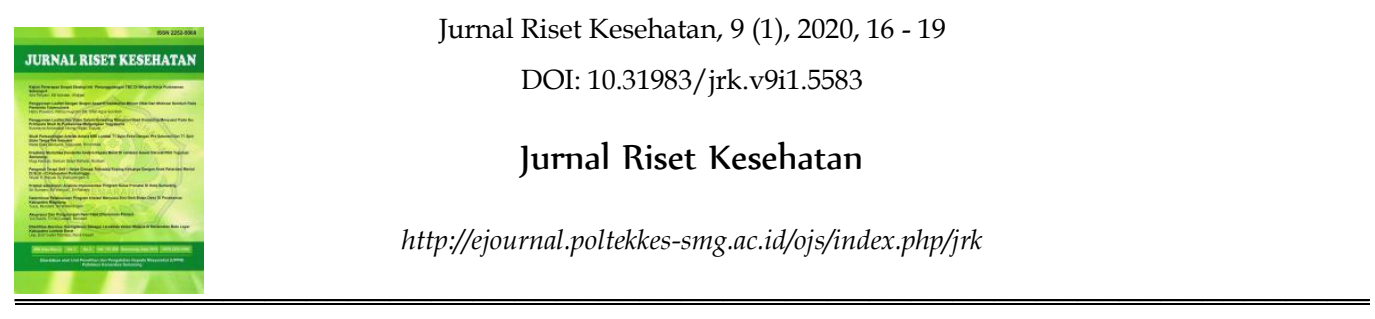

\title{
DETECTION OF THE RESISTANCE OF MYCOBACTERIUM TUBERCULOSIS FROM SPECIMENS WITH TB PATIENTS IN SEMARANG BALKESMAS
}

\author{
Widodo $\left.^{a *}\right)$; Djoko Priyatno ${ }^{b}$ \\ $a, b$ Jurusan Analis Kesehatan ; Poltekkes Kemenkes Semarang, \\ Jl. Wolter Monginsidi No.115, Pedurungan Tengah, Pedurungan, Kota Semarang, Indonesia
}

\begin{abstract}
The government has worked hard in an effort to eradicate tuberculosis by forming a program Temukan Obati Sampai Sembuh Tuberculosis (TOSS TBC) to free the Indonesian people from Tuberculosis in 2025. Directly Observed Treatment Short-course (DOTS) strategy treatment is the best effort in treating $\mathrm{TB}$, but other problems arise related to the treatment, one of which is the emergence of resistance to Obat Anti Tuberculosis (OAT). Detection of the occurrence of resistance of Mycobacterium tuberculosis from sputum specimens of tuberculosis patients in BALKESMAS Semarang used a non-experimental cross-sectional design with a non-intervention approach survey method. Sputum samples were from TB patients who did not convert during treatment. Percentage of culture results from 9 patients was 33.3. DST test from sensitive first-line OAT samples, morphological and size changes $(1.82-1.87 \mu \mathrm{m})$ shows that first-line drugs were still effective for treatment inpatients who took part in this study. Samples conducted as a study can still be treated with first-line drugs. Patients must be obedient to take medication for speed healing
\end{abstract}

Keywords: Mycobacterium tuberculosis, not conversion, resistance

\section{Introduction}

Tuberculosis cases in Central Java in 2017 were noted 42,272 cases out of a total population of $34,257,865$ with positive Acid-fast bacilli (AFB) cases of 18,248 (10,614 men and 7,734 women). The number of Case natification rates (CNR) was 123 and the number of Positive AFB was 53. Positive pulmonary tuberculosis coverage had cured 11,758 or $93.07 \%$-- 876 or $6.93 \%$ with complete treatment. The treatment success was 12,634 or $72.84 \%$ (Ministry of Health, RI, 2018).

The government has worked hard in an effort to eradicate tuberculosis by forming a program Temukan Obati Samapai Sembuh Tuberculosis (TOSS TBC) to free the Indonesian people from Tuberculosis in 2025. Directly

*) Corresponding Author (Widodo)

E-mail: widodo124@ymail.com

Observed Treatment Short-course (DOTS) strategy treatment is the best effort in treating $\mathrm{TB}$, but other problems arise related to treatment, one of which is the emergence of resistance to Obat Anti Tuberculosis (OAT).

The standard of treatment can be achieved with about $98 \%$ recovery and less than 5\% relapse if Isoniazid (INH), rifampicin (RMP), Ptrazinamide (PZA) and Entambutol (EMB) drugs are treated for 6 months. If the four drugs are reduced, RMP and INH will recur after 2 months and treatment will last longer (Zang and Yew, 2009).

Irregular drug exposure will cause spontaneous resistance because Mycobacterium tuberculosis has a wall layer that is resistant to acids. Morphologically, the Mycobacterium tuberculosis exposed to the anti-TB drug INH will experience changes in size and shape (Widodo, 2016). 


\section{Method}

This research was carried out in the Microbiology Laboratory of Campus III, Semarang Ministry of Health Polytechnic, Semarang Community Health Center and Health Laboratory and Testing Center of the Central Java Medical Center. This study used a nonexperimental cross-sectional design with no descriptive analytic intervention that takes phlegm specimens from patients suffering from tuberculosis. The number of samples was 9 specimens with inclusion criteria not to be converted for 2 months, microscopic examination, culture test, and Mycobacterium tuberculosis drug sensitivity test (DST).

\section{Result and Discussion}

Sputum samples obtained from Semarang Community Health Center (BALKESMAS Semarang) were carried out with microscopic examination directly by making sedian preparations measuring $3 \times 2 \mathrm{~cm}$ and then continued with Ziehl Neelsen staining and finally they were cultured on Jensen lowenstein media for 6-8 weeks at $37^{\circ} \mathrm{C}$.

Table 1. Results of Ziehl Neelsen Stain and Culture

\begin{tabular}{rccccccc}
\hline $\begin{array}{c}\text { No } \\
\text { Sample } \\
\text { code }\end{array}$ & $\begin{array}{c}\text { ZN } \\
\text { Stain }\end{array}$ & $\begin{array}{c}\text { Culture } \\
\text { results }\end{array}$ & PNB & $\begin{array}{c}\text { Niacin } \\
\text { Catalase } \\
\text { heat }\end{array}$ & $\begin{array}{c}\text { DST } \\
\text { INH } \\
\text { test }\end{array}$ \\
\hline 1 & X01 & N & NGR & - & - & - & - \\
2 & X02 & N & NGR & - & - & - & - \\
3 & X03 & N & NGR & - & - & - & - \\
4 & X04 & N & NGR & - & - & - & - \\
5 & X05 & N & 1 C & N & P & N & S \\
6 & X06 & N & NGR & - & - & - & - \\
7 & X07 & N & 2 C & N & P & N & S \\
8 & X08 & $1+$ & 5 C & N & P & N & S \\
9 & X09 & N & NGR & - & - & - & - \\
\hline N : Negative , P : Positive , C : Colony, \\
NGR: No Growth
\end{tabular}

The results in the table show that during intensive treatment and insertion, if the patient did not convert ZN's direct sputum examination to positive results, there is a possibility that there were still surviving $M$. tuberculosis in the sputum of the patients undergoing treatment therapy. The Percentage of culture results from nine patients was $33.3 \%$ of the patients who had sputum with $\mathrm{M}$. tuberculosis which can grow in LJ media.

\section{a. Size of M. tuberculosis}

The morphological variations of $M$. tuberculosis are classified into two categories that are often encountered in the exponential phase with the growth of stems with variations in form $\mathrm{V}, \mathrm{Y}$ or branching. When under stress conditions or unfavorable environments, they are round, oval, or crooked to resemble the letter L (Velayati and Farnia, 2012; Daniel, 2009).

Table 2. size and morphology damge

\begin{tabular}{lcccc}
\hline Sample & $\begin{array}{c}\text { Growth } \\
\text { Colony }\end{array}$ & $\begin{array}{c}\text { Average } \\
\text { Size }\end{array}$ & $\begin{array}{c}\text { Normal } \\
\text { Percentage } \\
(\mathbf{\%})\end{array}$ & $\begin{array}{c}\text { Abnormal } \\
\text { Percentage } \\
(\mathbf{\%})\end{array}$ \\
\hline H37Rv & 300 & 2.08 & $100 \%$ & 0 \\
X05 & 1 & 1.82 & 0 & $100 \%$ \\
X07 & 2 & 1.87 & 0 & $100 \%$ \\
X08 & 5 & 1.85 & 0 & $100 \%$ \\
\hline
\end{tabular}

The results of the table show that the percentage of growth rates indicates that $\mathrm{M}$. tuberculosis from pure iculture had more growth compared to samples from sputum of $\mathrm{TB}$ patients who did not convert treatment. The size decreased due to exposure to the drug so that the size of $M$. tuberculosis underwent this shortening because metabolic rates in response to exposure (stress) tended to be favorable for continuous growth under conditions of nutrient deficiencies or other factors that could cause imbalances in cellular metabolism (Baek et al, 2011).

The size of M. Tuberculosis shrinks when it is compared with pure culture. When experiencing treatment, the average size is 1.82 $1.87 \mu \mathrm{m}$ while the pure culture is $2.08 \mu \mathrm{m}$.

\section{b. Morphology of M. tuberculosis with ZN staining \\ Observations using digital cameras are used} to improve the image by adjusting the brightness, contrast and color of the image so that the pixel value is good (Mukti and Kale, 2011). 


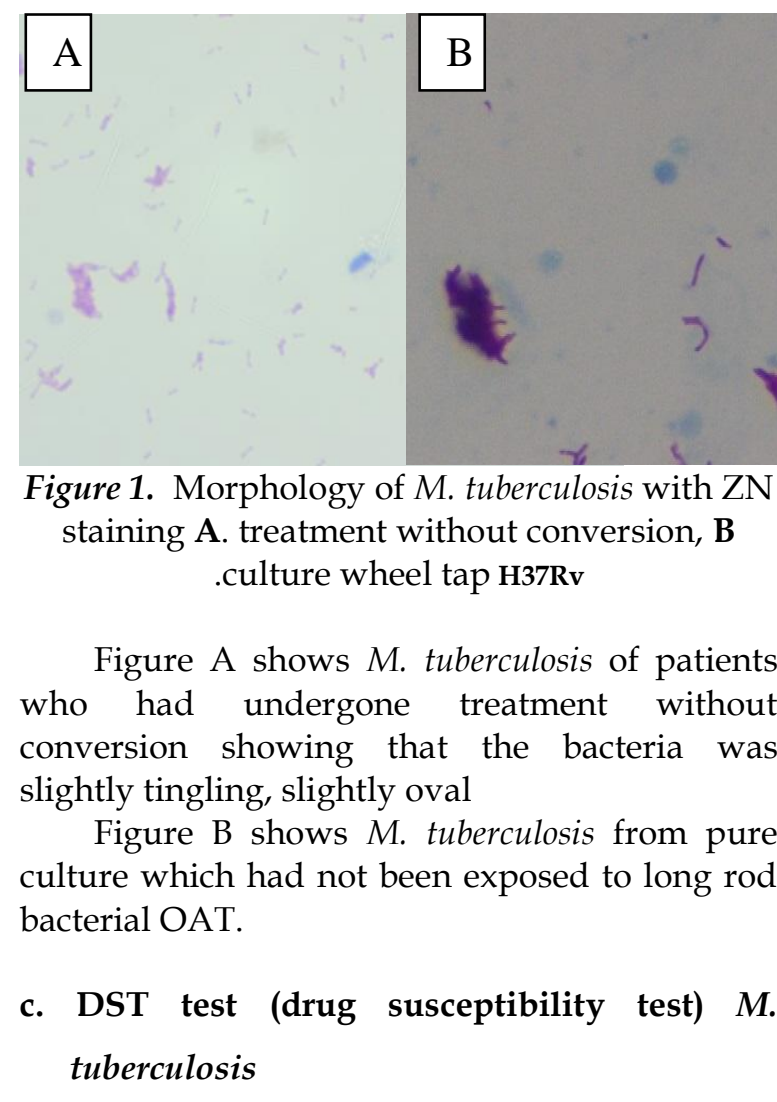

Examination of culture with the drug susceptibility test from 9 cultures carried out all the results of sensitive shows can be seen from the table below.

Table 3. DST test (drug susceptibility test) M. tuberculosis

\begin{tabular}{ccccc}
\hline Sampel & \multicolumn{5}{c}{ Prosentase Resistensi } \\
\cline { 2 - 5 } & INH & Rif & Enta & Strep \\
\hline X01 & - & - & - & - \\
X02 & - & - & - & - \\
X03 & - & - & - & - \\
X04 & - & - & $\bar{S}$ & $\bar{S}$ \\
X05 & S & S & - & - \\
X06 & - & - & - & S \\
X07 & S & S & S & S \\
X08 & S & S & S & - \\
X09 & - & - & - & - \\
\hline \multicolumn{5}{c}{$=$} \\
S indicates no growth \\
\multicolumn{5}{c}{ indicates sensitive drug }
\end{tabular}

The results of the examination in the table show that all samples grown from culture results were still sensitive to first-line OAT with concentrations of streptomycin $4 \mathrm{mg} / \mathrm{l}$, INH 0.2 $\mathrm{mg} / \mathrm{l}$, Rifampicin $40 \mathrm{mg} / \mathrm{l}$, Ethambutol $2 \mathrm{mg} / \mathrm{l}$, so that the first line drug can still be used for treatment.

\section{Conclusion and Sugestion}

Ther Fesults of examination of patients who were not converted during OAT treatment of TB disease from 9 samples indicated that 3 samples grew at the time of culture; and DST test was sensitive for all morphological changes of $\mathrm{M}$. tuberculosis during the treatment process.

The research was carried out by considering factors related to medication adherence and more sample coverage.

\section{5. Ācknowledgements}

Thanks to the Director of the Health Ministry of Polytechnic of Semarang, the Semarang Ministry of Health Polytechnic DIPA which has funded the research, Elly Karina, Nur Jani, Tri Sugiatmini who have assisted the research process

\section{References}

Baek, S. H., Li, A. H., \& Sassetti, C. M. 2011. Metabolic regulation of mycobacterial growth and antibiotic sensitivity. PLoS Biol 9(5): e1001065.

Daniel TM. Chapter 1: The history of tuberculosis: Past, present, and challenges for the future. In: Schaaf HS ZA, editor. Tuberculosis: A comprehensive clinical reference. 1st ed. Edinburgh: Saunders Elsevier; 2009. p. 1-7.

Kementerian Kesehatan, R. I. (2018). Infodatin pusat data dan informasi kementerian kesehatan RI. Tuberculosis . Jakarta Selatan.

Kementerian Kesehatan, R. I. (2018). Data dan Informasi Profil Kesehatan Indonesia 2017. Pusat Data dan Informasi Kementrian Keshatan RI.

Kochi, A., Vareldzis, B., \& Styblo, K. (1993). Multidrug-resistant tuberculosis and its control. Research in microbiology, 144(2), 104-110.

Malhotra, D., Portales-Casamar, E., Singh, A., Srivastava, S., Arenillas, D., Happel, C., Biswal, S. (2010). Global mapping of binding sites for Nrf2 identifies novel targets in cell survival response through chip-seq profiling and network analysis. Nucleic Acids Research, 38(17), 5718-5734. https://doi.org/10.1093/nar/gkq212

Mukti, J., \& K.V., K. (2011). Analysis of ZNStained Sputum Smear enhanced images for identification of 
Mycobacterium Tuberculosis Bacilli cells. International Journal of Computer Applications, 23(5), 10-16. https://doi.org/10.5120/2882-3760

Takayama, K., Wang, L., \& David, H. L. 1972. Effect of isoniazid on the in vivo mycolic acid synthesis, cell growth, and viability of Mycobacterium tuberculosis. Antimicrobial agents and chemotherapy, 2(1): 29-35.

Velayati, A. A., \& Farnia, P. (2012). Morphological characterization of Mycobacterium tuberculosis. In Understanding TuberculosisDeciphering the Secret Life of the Bacilli. InTech.

Widodo, W., Irianto, A., \& Pramono, H. (2017). Karakteristik Morfologi Mycobacterium tuberculosis yang Terpapar Obat Anti
TB Isoniazid (INH) secara Morfologi.

Biosfera, 33(3), 109. https://doi.org/10.20884/1.mib.2016.3 3.3.316

Zhang, Y. and Yew, W.W., 2009. Mechanisms of drug resistance in Mycobacterium tuberculosis [State of the art series. Drug-resistant tuberculosis. Edited by CY. Chiang. Number 1 in the series]. The International Journal of Tuberculosis and Lung Disease, 13(11), pp.1320-1330.

Zhang Ying CV, William R, Jacobs Jr .2005. Mechanisms of Drug Resistance in Mycobaterium tuberculosis in Tuberculosis and the Tubercle Bacillus :115-140 